\title{
The relative contributions of slope gradient and vegetation cover on erosion characteristics of riparian slopes along the lower Yellow River, China
}

\author{
Zihao Cao ${ }^{1}$, Qinghe Zhao ${ }^{2}$, Shengyan Ding ${ }^{2}$, and Yifan Zhang ${ }^{2}$ \\ ${ }^{1}$ Beijing Normal University Faculty of Geographical Science \\ ${ }^{2}$ Henan University
}

May 17, 2021

\begin{abstract}
Slope gradient and vegetation cover play key roles in soil erosion process. Exploring the effects of slope gradient and vegetation cover on runoff and sediment yielding characteristics is therefore of great importance for minimizing soil erosion. In this work, based on field scouring experiments on the riparian slopes of the lower Yellow River, China, variation in total runoff, accumulative runoff sediment concentration, erosion sediment yield, and sediment particle size composition under four slope gradients $\left(5^{\circ}, 10^{\circ}, 15^{\circ}, 20^{\circ}\right)$ and three vegetation cover levels $(0 \%, 15 \%, 30 \%)$ were analyzed. Runoff and sediment yield were greatly influenced by slope gradient at steep slope gradients $\left(15^{\circ}\right.$ and $\left.20^{\circ}\right)$, while they were mainly affected by vegetation cover at medium slope gradients $\left(5^{\circ}\right.$ and $\left.10^{\circ}\right)$. The main enriched particle size of the eroded sediment showed a trend of first increasing and then decreasing with the increasing slope gradient. There was an interaction between slope gradient and vegetation cover, the effect of vegetation cover on erosion sediment yield weakened gradually with increasing slope gradient (at medium slope gradients of $5^{\circ}$ and $\left.10^{\circ}\right)$, while the effect of slope gradient increased at steep slope gradients $\left(15^{\circ}\right.$ and $\left.20^{\circ}\right)$.
\end{abstract}

The relative contributions of slope gradient and vegetation cover on erosion characteristics of riparian slopes along the lower Yellow River, China

Zihao Cao ${ }^{\mathrm{a}}$, Qinghe Zhao ${ }^{\text {* }}$, Shengyan Ding ${ }^{\mathrm{a}}$, Yifan Zhang ${ }^{\mathrm{a}}$

a Key Laboratory of Geospatial Technology for the Middle and Lower Yellow River Regions, College of Environment and Planning, Henan University, Kaifeng 475004, China

b State Key Laboratory of Earth Surface Processes and Resources Ecology, Faculty of Geographical Science, Beijing Normal University, Beijing 100875, China

*Corresponding author: Qinghe Zhao

College of Environment and Planning,

Henan University,

Jinming Avenue, Longting District,

Kaifeng 475004, P. R. CHINA.

Tel.: +86-15903783593

E-mail: zhaoqinghe@henu.edu.cn

\section{ABSTRACT}


Slope gradient and vegetation cover play key roles in soil erosion process. Exploring the effects of slope gradient and vegetation cover on runoff and sediment yielding characteristics is therefore of great importance for minimizing soil erosion. In this work, based on field scouring experiments on the riparian slopes of the lower Yellow River, China, variation in total runoff, accumulative runoff sediment concentration, erosion sediment yield, and sediment particle size composition under four slope gradients $\left(5^{\circ}, 10^{\circ}, 15^{\circ}, 20^{\circ}\right)$ and three vegetation cover levels $(0 \%, 15 \%, 30 \%)$ were analyzed. Runoff and sediment yield were greatly influenced by slope gradient at steep slope gradients $\left(15^{\circ}\right.$ and $\left.20^{\circ}\right)$, while they were mainly affected by vegetation cover at medium slope gradients $\left(5^{\circ}\right.$ and $\left.10^{\circ}\right)$. The main enriched particle size of the eroded sediment showed a trend of first increasing and then decreasing with the increasing slope gradient. There was an interaction between slope gradient and vegetation cover, the effect of vegetation cover on erosion sediment yield weakened gradually with increasing slope gradient (at medium slope gradients of $5^{\circ}$ and $10^{\circ}$ ), while the effect of slope gradient increased at steep slope gradients $\left(15^{\circ}\right.$ and $\left.20^{\circ}\right)$.

Key words : riparian zone; runoff and sediment yielding characteristics; slope gradient; vegetation cover

\section{Introduction}

The Yellow River basin in China is one of the most severely eroded regions in the world (Wang et al., 2016). In particular, slope erosion, which is related to climate, soil properties, slope gradient, vegetation cover, and their interactions (Römkens et al., 2001; Sachs and Sarah, 2017), is very common in the Yellow River basin. Among these factors, climate and soil are relatively stable and change little over short periods. Variation in slope erosion is mainly driven by changes in slope gradient and vegetation cover, both of which can retard or accelerate the process of soil erosion (Joshi and Tambe, 2010; Alatorre et al., 2011; Sharma et al., 2011; Donjadee and Chinnarasri, 2012; Mohamadi and Kavian, 2015). Understanding their relative contribution to soil erosion is an important question for many stakeholders of the Yellow River.

Researchers have long known the importance of vegetation in soil erosion (Srivastava et al., 2010; Sandercock and Hooke, 2011), and the observation of a strong correlation between vegetation cover and runoff and soil loss is common (Nunes et al., 2011; Xin et al., 2011; Gurnell, 2014; Duan et al., 2016). Subsequently, several studies under different environmental conditions have demonstrated the positive effect of vegetation cover in reducing soil erosion and improving the ecological environment (Srivastava et al., 2010; Mohammad and Adam, 2010; Nunes et al., 2011). From the canopy to the roots, vegetation cover of different spatial structure can weaken the intensity of soil erosion caused by rainfall and runoff scouring by reducing slope sediment transport and soil and water loss (Molina et al., 2010; Srivastava et al., 2010; Duan et al., 2016). Moreover, vegetation cover can increase soil infiltration and water conservation (Chen et al.,2007), reduce runoff and flow velocity (Vásquez-Méndez et al., 2010), and improve soil corrosion resistance and anti-scourability (Wang et al., 2016). Generally, runoff generation and sediment yield decrease with increasing vegetation cover (Breshears et al., 1998; Zhang et al., 2015b; Wang et al., 2016), and different vegetation covers can produce different effects on soil erosion process (Srivastava et al., 2010; Sharma et al., 2011; Wang et al., 2016). For example, a study on the purple soil in Southwest of China showed that high vegetation cover reduces runoff and sediment yield (Liu et al., 2015a). A study of slope rainfall and runoff erosion under different herbaceous vegetation cover found that soil erosion intensity decreased significantly at vegetation cover in the range of $20 \% \sim 60 \%$, while soil erosion became more serious when the vegetation cover was less than $20 \%$ (Zhu et al., 2010).

Slope gradient is probably the most important topographic factor controlling nutrient, contaminant, and particle transfer within a watershed (Valmis et al., 2005; Sirjani and Mahmoodabadi, 2014; Zhao et al., 2015a). Slope is the dominant factor associated with the hydrological response in soil erosion processes, and has been studied via numerical simulation, experiments, and analytical solutions (Bergkamp, 1998; Assouline and Ben-Hur, 2006; Joshi and Tambe, 2010; Sirjani and Mahmoodabadi, 2014). Further, a better understanding of relationship between slope gradient and slope erosion is important in predicting soil erosion and the conservation of soil and water resources (Assouline and Ben-Hur, 2006; Zhao et al., 2015a; Wu et al., 2018). However, due to differences in experimental methods (Zingg, 1940; Fox and Bryan, 2000; Joshi and Tambe ,2010; Sirjani and Mahmoodabadi, 2014) and the regional environment (Valmis et al., 2005; 
Assouline and Ben-Hur, 2006; Liu et al., 2015b; Zhao et al., 2015a), the observed results are often different. On the one hand, erosion sediment yield rate has been shown to be greater on steeper slopes (Assouline and Ben-Hur, 2006; Wu et al., 2018). On the other hand, there is a critical slope gradient for soil erosion processes. For example, the first empirical relationships between soil erosion and slope gradient established by Zingg (1940) indicated that the amount of soil erosion increased with increasing slope, while in the early version of the USLE and its revised version (RUSLE), soil erosion was predicted as a power and liner function of slope gradient respectively (Fox et al., 1997; Liu et al., 2017). Moreover, Zhang et al. (2015) found that the relationship between erosion sediment particle size and slope was linearly negatively only under a certain slope gradient range. Nonetheless, a number of field observation data and indoor artificial rainfall experiment data showed that the relationship between soil erosion and slope gradient can be established only within a certain slope gradient range. When the slope gradient exceeds the threshold value, the relationship between them could even reverse, indicating that there may be a critical slope gradient in slope erosion processes (Bergkamp, 1998; Zhao et al., 2015a; Liu et al., 2017).

The riparian zone is an important ecotone, exchanging energy and information between streams and hillslopes, and has unique ecosystem structure and ecological service functions (Mander et al., 2005; Stella et al., 2013; Méndez-Toribio et al., 2014; Tang et al., 2014). The main factors affecting the structure and function of riparian ecosystems are geomorphology and vegetation (Srivastava et al., 2010; Stella et al., 2013; Méndez-Toribio et al., 2014; Cadol and Wine, 2017). Previous studies have shown that the riparian zone serves an important function in reducing soil erosion via intercepting soil particles in surface runoff, and preventing scouring and collapse (Srivastava et al., 2010; Méndez-Toribio et al., 2014). However, most studies have focused on the effect of only a single control factor (e.g., slope gradient, or vegetation cover) on soil erosion (Srivastava et al., 2010; Stella et al., 2013; Cadol and Wine, 2017). Yet, studies considering the interaction between slope gradient and vegetation cover are relatively few. Moreover, existing research results are mainly from simulated rainfall experiments indoors or outdoors on slopes with artificially planted vegetation (Srivastava et al., 2010; Sirjani and Mahmoodabadi, 2014). Documenting erosion and sediment yield under natural vegetation conditions is rarely considered, especially in the riparian zone. These issues are critical for the Yellow River, which is world-famous on account of heavy silt-carrying, and in combination with long-term impact of human activities, its riparian zone is suffering serious threats.

As the last barrier to prevent water and sand from entering rivers, the riparian zone plays an important role in soil and water conservation (Srivastava et al., 2010; Méndez-Toribio et al., 2014). According to the discharge per unit width produced by heavy rain at the plot scale in the study area, we ran a series of field runoff scouring experiment to analyze soil erosion and sediment yield variation under different slope gradients and vegetation covers. The rainfall experiment which can be found in many specialized literatures (Aoki and Sereno, 2006; Arnaez et al., 2007; Verbist et al., 2009), and is an important way to analyze the different processes involved in erosion (Sangüesa et al., 2010). Because the riparian zone is long and narrow and the erosion effect of a rainfall event is usually less than that of runoff from upslope, we conducted a field runoff scouring experiment.

Soil erosion is generally shown to be highly scale-dependent and vary significantly across different spatial scales, such as plots, watersheds, and regions (Chen et al., 2012). In order to get a better understanding of soil erosion issues on riparian slope of the lower Yellow River, this study was conducted at the plot scale. The advantages and progresses of soil erosion research at the plot level are significant. During the past several decades, some experimental techniques and (semi-) quantitative methods have documented soil erosion processes at the plot scale (Chen et al., 2012). Meanwhile, field measurements have provided large quantities of basic data and important parameters for model calibration and validation, such as flow length (FL), directional leakiness index (DLI), the universal soil loss equation (USLE), and the revised universal soil loss equation (RUSLE) (Chen et al., 2012). Processes at these small scales could also reflect key changes in direction or trends at regional or global scales (Muñoz-Robles et al., 2013).

The main purpose of this study was to document the relative contribution of slope gradient and vegetation cover to erosion characteristics of riparian slope along the lower Yellow River, using field runoff scouring 
experiments. Specifcally, we examined: (1) runoff processes under different slope gradients and vegetation covers; (2) sediment yield characteristics under different slope gradients and vegetation covers; and (3) the relative contribution of slope gradient and vegetation cover to slope erosion and sediment yield in the riparian zone of the lower Yellow River.

\section{Material and methods}

\subsection{Study area}

The experiment was conducted on riparian slopes of the lower Yellow River, Zhongmu County, Henan Province, China (Fig. 1a, b), from September to October 2015. Zhongmu County is located at the south bank of the Yellow River (N 34 26'-34deg56', E 113deg46'-114deg12') with a total area of $1406 \mathrm{~km}^{2}$. The climate in Zhongmu County is a typical warm temperate continental monsoon climate, characterized by mild windy springs (April-June), hot rainy summers (July-September), and cool dry autumns and winters (OctoberMarch). The mean annual temperature is $14.2 \mathrm{oC}$, and the maximum and minimum monthly temperatures occur in July and January respectively (Geng et al., 2012; Zhao et al., 2016; Zhao et al., 2015b). The mean annual precipitation is $616 \mathrm{~mm}$, with significant seasonality; most precipitation occurs during the rainy season (Geng et al., 2012; Zhao et al., 2016; Zhao et al., 2015b). Influenced by historical floods of the Yellow River, sedimentary rocks in Zhongmu County are mainly alluvium and diluvium, and soils contain much sub-sand and silt-sand (Zhao et al., 2015b). Vegetation in Zhongmu County is limited by the climatic characteristics and soil and water conditions. The dominant plant species in this area include Salix babylonica, Populus L. , and grass (Setaria viridis ). The families Gramineae, Compositae, Leguminosae, and Brassicaceae occupy an important position in the lower Yellow River riparian flora. While the main agricultural crops in this area are wheat (Triticum aestivum L. ) and maize (Zea mays L. ) (Zhao et al., 2015b).

[Insert Figure 1]

\subsection{Experimental design and methods}

According to the change of riparian slope in topographic structure, 4 field natural slopes with few human disturbances (5deg, 10deg, 15deg, 20deg) were selected in the riparian zone (Fig. 1c). Meanwhile, the soil properties and vegetation types were similar among the 4 slopes (Table 1). Four experimental plots were set up on the slope of the riparian zone and each experimental plot was surrounded by steel flumes (300 $\mathrm{cm}$ length $\times 100 \mathrm{~cm}$ width $\times 30 \mathrm{~cm}$ height) so as to separate the plots from the surrounding environment to prevent runoff from overflowing.

\section{[Insert Table 1]}

Vegetation patches are severely fragmented according to field survey in the study area of riparian zone, therefore, 3 vegetation cover in this study were preliminarily designed as $0 \%, 15 \%$ and $30 \%$ respectively in the experimental plots. The extraction method of vegetation cover in the experimental plots is that: Firstly, simply weed the grass and repair the ground surface; Secondly, the vertical photography of the experimental plots is taken with a camera (Canon SX60 HS), Finally, Photoshop CS4 software (Adobe Systems Inc., San Jose, California, USA) was used to process the photos to obtain vegetation cover. In order to ensure the accuracy of vegetation cover, the process is repeated many times until the vegetation cover obtained is within $0.5 \%$ of the error compared with the actually designed vegetation cover.

The experimental system included a storage water tank, a water scouring supply system (composed of a constant head scouring setup, water pipes, water pump, and water valve), steel catchment collector, and plastic container (Fig. 1e). The water tank was filled with water to ensure consistent hydraulic pressure throughout the experiment. The constant head scouring setup was placed at the top of the steel flume to keep a uniform water flow into the experimental plots, and a steel catchment collector was placed at the foot of the steel flume to collect the runoff and sediments. Then, a plastic container $(20 \mathrm{~L})$ was used to catch the runoff and sediments at the outlet of the steel catchment collector. According to the discharge per unit width produced by the heavy rain in the study area, the scouring intensity was set to $15 \mathrm{~L} / \mathrm{min}$. In order to 
avoid any effects of river sediment on the experiment, the water in the tank was obtained from underground through a water pump.

The runoff scouring experiments were conducted with 4 slope gradients (5deg, 10deg, $15 \mathrm{deg}, 20 \mathrm{deg})$ and 3 vegetation cover levels $(0 \%, 15 \%, 30 \%)$, respectively. A total of 12 treatments were conducted, and each treatment lasted $30 \mathrm{~min}$ and repeated twice. Considering the heterogeneity in the initial soil moisture of the different slopes of the experimental plot, a sprinkle water process was applied to soil moisture uniform. The volume of the sprinkling water depended on the saturation of the soil surface, which should be fully saturated with no runoff. The water discharge was adjusted close to $15 \mathrm{~L} / \mathrm{min}$ and repeated 3 times to ensure the error was within 2\%. Runoff-initiating time was measured by a stopwatch at the beginning of each experiment. During each experiment, runoff and sediment samples were collected in a marked plastic container at $1 \mathrm{~min}(0-5 \mathrm{~min})$ and then at $5 \mathrm{~min}(5-30 \mathrm{~min})$ intervals for a total of 10 samples. The container was changed several times in each interval, and the total runoff volume of each interval was recorded.

\subsection{Date measurement and calculation}

In this study, the total runoff within the prescribed time was the amount of runoff collected at each time period. The collecting sediment was dried in a oven at $105 \mathrm{degC}$ for at least $24 \mathrm{~h}$ until constant weight, and then dry weight determined. Sediment concentration was obtained by dividing sediment yield by the discharge of water. Sediment particle size was analyzed by a MS2000 Laser Size Classifier (Malvern, UK).

To assess the interaction between slope gradient and vegetation cover on runoff and sediment yield, we revised the approach of Cheng et al. (2007) and Ma et al. (2013) as follows:

\section{Hosted file}

image1.wmf available at https://authorea.com/users/414205/articles/522312-the-relativecontributions-of-slope-gradient-and-vegetation-cover-on-erosion-characteristics-ofriparian-slopes-along-the-lower-yellow-river-china

\section{(1)}

where $I S Y_{s g}$ is the increment of sediment yield caused by a slope gradient (grams), which should be taken as the absolute value. $S Y_{b l}$ is the sediment yield of bare land (grams), $X$ is the gradient of the slope (in this case $10 \mathrm{deg}, 15 \mathrm{deg}$, or $20 \mathrm{deg}$ ).

To include variation in vegetation cover, we modified equation 1 as follows:

\section{Hosted file}

image2.wmf available at https://authorea.com/users/414205/articles/522312-the-relativecontributions-of-slope-gradient-and-vegetation-cover-on-erosion-characteristics-ofriparian-slopes-along-the-lower-yellow-river-china

where $I S Y_{v c}$ is the increment of sediment yield (in grams) caused by vegetation cover. $S Y_{v c}$ is the sediment yield under vegetation cover (grams), $S Y_{b l}$ is the sediment yield of the bare land (grams), $X$ is the slope gradient (again, 10deg, 15deg, or 20deg).

\section{Hosted file}

image3.wmf available at https://authorea.com/users/414205/articles/522312-the-relativecontributions-of-slope-gradient-and-vegetation-cover-on-erosion-characteristics-ofriparian-slopes-along-the-lower-yellow-river-china

(3)

\section{Hosted file}


image4.wmf available at https://authorea.com/users/414205/articles/522312-the-relativecontributions-of-slope-gradient-and-vegetation-cover-on-erosion-characteristics-ofriparian-slopes-along-the-lower-yellow-river-china

\section{(4)}

where $I S Y_{t}$ is the increment of total sediment yield $(\mathrm{g}), R C I_{s g}$ is the relative contribution index of the slope gradient to sediment yield.

\section{Hosted file}

image5.wmf available at https://authorea.com/users/414205/articles/522312-the-relativecontributions-of-slope-gradient-and-vegetation-cover-on-erosion-characteristics-ofriparian-slopes-along-the-lower-yellow-river-china

\section{(5)}

where $R C I_{v c}$ is the relative contribution index of the vegetation cover to sediment yield.

We explored the interaction between slope gradient and vegetation cover on sediment yield using two-way ANOVA and the relative contribution index in the SPSS Statistics 17.0 software (SPSS Inc., Chicago, Illinois, USA). All figures were made in Origin Lab 9.0 software (Origin Lab Inc., USA).

\section{Results}

\subsection{Variation in total runoff}

On the four slopes, total runoff under different vegetation covers was slow at first ( $0-5$ mins), then increased rapidly (5-10 min), and then leveled off (10-30 mins) (Fig. 2). Based on these runoff data curves, total runoff under $0 \%$ vegetation cover was slightly greater than runoff under the other two vegetation covers at first, but by 30 mins runoff under $0 \%$ cover was similar or lower than $15 \%$ and $30 \%$, suggesting that the effect of surface condition and infiltration of spatial heterogeneity on runoff was considerable.

\section{[Insert Figure 2]}

Slope and vegetation are the primary factors affecting runoff, and different slopes and vegetation covers can generate varying runoff. Fig. 3 shows that the features of mean runoff and runoff difference between different vegetation covers. Duration of scouring time, the mean runoff and total runoff showed significant differences between different vegetation covers on the $5 \mathrm{deg}$ and 10deg slope, while the difference was not significant on the 15deg slope and 20deg slope (Fig. 3).

[Insert Figure 3]

\subsection{Variation in sediment}

\subsubsection{Variation in accumulative runoff sediment concentration}

The accumulative runoff sediment concentration was greater on steeper slopes (Fig. 4). For a given slope, however, sediment concentration was lower with greater vegetation cover. Interestingly, the difference between sediment concentrations in different vegetation covers increased with slope: accumulative runoff sediment concentration at the $5 \mathrm{deg}$ slope under different vegetation covers was low (maximum and minimum values were about $1.4 \mathrm{~kg} / \mathrm{m}^{3}$ and $0.7 \mathrm{~kg} / \mathrm{m}^{3}$, respectively), whereas at 20deg slope sediment concentration varied between 19.7 and $7 \mathrm{~kg} / \mathrm{m}^{3}$. Therein, the difference of accumulative runoff sediment concentration under different vegetation covers increased rapidly (5deg-10deg slope), then leveled off (10deg-15deg slope) , and then increased rapidly (15deg-20deg slope) (Fig. 4).

[Insert Figure 4]

\subsection{Variation in erosion sediment yield}


In all four slopes and most vegetation covers, erosion sediment yield was greatest in the first 5 minutes (Fig. 5). Thereafter, sediment yield dropped to less than a third of the maximum value and remained relatively constant throughout the rest of the sampling period. The interaction of slope with vegetation cover was as expected: on steeper slopes more sediment eroded in plots with $0 \%$ vegetation cover. On all slopes, $30 \%$ vegetation cover effectively decreased sediment erosion to almost zero.

\section{[Insert Figure 5]}

Under different vegetation covers, the difference of erosion sediment yield at the 5deg slope was smaller (Fig. 6 ). Meanwhile, under vegetation covers and slopes as well as their combined effects, the difference of erosion sediment yield at the 10deg slope with $30 \%$ vegetation covers was smaller too (Fig. 6c). On the whole, the difference of erosion sediment yield was larger at the 10deg and 15deg slope with different vegetation covers and it was significantly larger than that at $5 \mathrm{deg}$ slope. At the $20 \mathrm{deg}$ slope with $0 \%$ and $30 \%$ vegetation covers, however, the difference was smaller and it was gradually smaller than that at $15 \mathrm{deg}$ slope. The result indicated that the effect of vegetation covers, slope factor and their interaction on erosion sediment yield was considerable at the $10 \mathrm{deg}$ and 15 degslope.

[Insert Figure 6]

\subsection{Variation in sediment particle composition}

Sediment particle size composition varied significantly under different slope gradients and vegetation cover combinations (Fig. 7). The patterns for Dx (10) and Dx (50) were similar: the smallest particles were recovered at the $5 \mathrm{deg}$ slope, suggesting runoff only transported very small clay particles and fine powder at this gradient. Under different vegetation covers, the enriched sediment particles were mainly coarse powder grains and very fine sand on the slope less than $15 \mathrm{deg}$, and mainly coarse powder grains on the slope more than 15deg. Curiously, the plot with $15 \%$ vegetation cover and 15degslope had exceptionally high volume of particles.

The patterns for Dx (90) were different from Dx (10) and Dx (50), with much more variation in abundance of large particles. The sediment particles were mainly fine sand and very fine sand on slopes less than $15 \mathrm{deg}$, whereas sediment particles from $15 \mathrm{deg}$ slope under different vegetation covers were coarse sand, medium sand, and very fine sand, respectively.

\section{[Insert Figure 7]}

\subsection{Contribution of slope gradient and vegetation cover to sediment yielding}

The contribution index of vegetation cover and slope to accumulative sediment yield and runoff sediment concentration varied with slope (Fig. 8). On the flattest slope (5deg), the sediment yield was almost entirely affected by vegetation cover. On slopes $>10 \mathrm{deg}$, the contribution of slope gradient on sediment yield ranged from 0.51 to 0.6 . From the $10 \mathrm{deg}$ slope, the sediment yield caused by slope gradient was greater than that of vegetation cover.

\section{[Insert Figure 8]}

These results were supported by the two-way ANOVA, which showed that the slope gradient had significant effects on runoff sediment concentration, accumulative sediment yield, and erosion sediment yield (Table 2 ), whereas vegetation cover had a significant effect only on the accumulative sediment yield and erosion sediment yield. The interaction between slope gradient and vegetation cover was not significant for any of the three ANOVA modes of sediment yield.

[Insert Table 2]

\section{Discussion}

\subsection{Effects of slope gradient and vegetation cover on runoff}


In a field-based runoff scouring experiment, we found that variation of total runoff under different vegetation covers are divided into three stages (slow at first in 0 to 5 mins, then increased rapidly in 5 to $10 \mathrm{~min}$, and then leveled off in10 to 30 mins). The complicated phenomenon is due to the overall effects of several factors including scouring intensity, surface conditions (roughness, sealing layer on topsoil), vegetation covers, overland flow continuity, soil particles and infiltration capacity etc. (Lavee and Poesen, 1991; Cerda, 2001; Chen et al., 2013). These factors have different effects on the runoff. For example, the scouring intensity affected sealing layer formation (surface conditions) which can significantly reduce infiltration rates (Assouline and Ben-Hur, 2006). Meanwhile, soil infiltration rates is constantly changing. It is also affected by many factors including soil moisture, soil texture, surface roughness, and scouring characteristics. During the process of runoff generation, all these factors are interactive and the overall effects of them are far from perfectly understood (Zhang et al., 2018). In this study, runoff is unstable and changes slowly at first in 0 to 5 mins due to the effect of surface roughness and overland flow continuity. With scouring time increasing, runoff increased rapidly in 5 to $10 \mathrm{~min}$ is affected by sealing layer formation. Then the runoff became leveling off in the later scouring period when spatial heterogeneity of infiltration is basically stable.

In addition, when slope gradient was less than $15 \mathrm{deg}$, the difference of mean runoff and total runoff was obvious under different vegetation covers, while when slope was steeper than 15deg, the difference was less clear. Variation in runoff that occurred on slopes more than $15 \mathrm{deg}$ was always lower than that on slopes less than $15 \mathrm{deg}$, indicating there is a critical slope of runoff change. This result also suggested that the accumulative infiltration on slopes less than $15 \mathrm{deg}$ was higher than that on slopes more than 15deg. This is not exactly the same as the results by some study that the critical slope gradient for overland flow. For example, A studies have found that infiltration decreased greatly with increasing slope when the slope was less than 18deg, while infiltration was less influenced by slope beyond 18deg (Cheng et al., 2008). Another study conducted by Jin (1996) indicated that the turning point of slope was 15deg. Although the results are different, they are basically between 15deg and 20deg slope (Liu et al., 2017), which supports the results of the present study.

Besides slope gradient, the difference in runoff may be also attributed to vegetation, and interactions between slope gradient and vegetation. Similarly, Sadeghi et al. (2013) emphasized the complex circumstances which govern the interaction between runoff and soil loss. Some research on the effects of vegetation cover on slope runoff erosion indicated that when rainfall intensity reached a steady condition, runoff was negatively correlated with vegetation cover (Joshi and Tambe, 2010; Mohammad and Adam, 2010; Nunes et al., 2011; Zhu et al., 2010; Wang et al., 2016), these studies only considered the effects of vegetation cover and rainfall. However, we found that under different vegetation covers, the changes in runoff tended to be consistent on slopes $>15 \mathrm{deg}$, and the runoff date curves were basically coincident on the $20 \mathrm{deg}$ slope, indicating the effect of vegetation cover on runoff was more significant at medium slope gradients (5deg and 10deg), and slope was more significant at steep slope gradients (15deg and 20deg). According to the results of this study, the $15 \mathrm{deg}$ slopes may be a critical threshold for the effect of slope gradient and vegetation cover to overland flow and soil loss.

\subsection{Effects of slope gradient and vegetation cover on sediment loss}

Runoff scouring is the main motive force of sediment loss, and slope gradient is an important factor affecting sediment loss (Zhang et al., 2015c). In this study, the erosion sediment yield decreased and reached a steady state with duration of scouring time under different slope gradients and vegetation covers, and also presented an overall increasing trend with increased slope gradient. This is because runoff during the initial runoff producing period was large, the decrease of infiltration resulted in the increase of runoff, so the sediment carried by runoff increased, but it gradually reached a steady state with increased infiltration (Wu et al., 2018). Moreover, the sediment yield increased with increased slope gradient is mainly because the component force of gravity increased along the down slope, thus increasing runoff velocity (Zhang et al., 2010), and enhancing sediment transport capacity (Li et al., 2006). Irrational production and management practices (For example, tillage practices, sand digging and engineering construction) destroy the riparian zone of the lower reaches of the Yellow River, resulting in soil loss increased greatly with increased slope gradient. The 
results are supported by Wang et al. (2017a) that the soil loss with wheat stubble cover slightly increased with increased slope gradient, and also supported by Wang et al. (2017b) that the capacity of tillage practices to reduce runoff and sediment decreased with increased slope. Therefore, the soil conservation measures of the riparian zone of the lower reaches of the Yellow River should be realize coordination between ecological protection and economic development. The idea is supported by Ai et al. (2017), for example, by engineering measures or restoring vegetation on severely-disturbed slopes to reduce runoff and sediment yield.

The results of this study are similar to the findings by Li et al. (2017) that the sediment concentration increased with increased slope gradient and decreased with increased vegetation cover. Actually, the effects of vegetation cover and slope gradient on erosion sediment yield were similar to that on runoff (Joshi and Tambe, 2010; Sirjani and Mahmoodabadi, 2014; Zhu et al., 2010). However, the erosion process becomes more complex as result of the interaction between vegetation cover and slope gradient. We found that the difference in accumulative runoff sediment concentration between different vegetation covers was obvious with increasing slope gradients. From the 10deg slope, the difference of accumulative runoff sediment concentration under different vegetation covers was gradually larger, and it was greater than that at the 5deg slope with smaller difference of runoff sediment concentration between different vegetation covers. This result could be related to the relative heterogeneity of soil texture of the riparian slope, since there was a thin layer of clay in the flat $5 \mathrm{deg}$ slope surface, leading to lower soil erosion under different vegetation covers. Besides, this result also indicates that the effect of vegetation factor on runoff sediment concentration was greater than that of slope gradient at medium slope gradients (5deg and 10deg), and the effect of slope gradient was greater than that of vegetation at steep slope gradients (15deg and 20deg). On the other hand, the difference of accumulative runoff sediment concentration between 10deg and 15deg slope was smaller under the same vegetation cover, speculating there is a transition, which is caused by the interaction between slope gradient and vegetation cover.

\subsection{Particle size distribution and composition of eroded sediment}

Regarding the particle size distribution of eroded sediments, Dx (10), Dx (50), and Dx (90) were mainly made up of silt, coarse powder grains and very fine sand, and very fine sand and fine sand, respectively, with the main enriched particle size increasing. Under the influence of overland runoff, the structurally unstable fine particles were most easily eroded, leading to different levels of fine particle enrichment (Berger et al., 2010). Moreover, the erosion sediment gradually showed a trend of coarse particles with longer scouring time (Schiettecatte et al., 2008). These results were similar to those obtained by Jiang et al. (2014). The enriched sediment of different particle sizes showed a trend of first increasing and then decreasing with increasing slope gradient, consistent with the results of Zhang et al. (2015). Under different vegetation covers, the difference of sediment particle size was obvious on slopes less than 15deg but not slopes greater than 15deg, suggesting that the flow velocity, which was influenced by slope gradient, can affect the movement of soil particles differently. When the slope was less than $15 \mathrm{deg}$, the larger sediment particles were not easily eroded and transported, meanwhile vegetation patches acted as sinks of sediment (Canton et al., 2012; Munoz-Robles et al., 2013), to effectively intercept and restrain sediment, thus the coarse particles were reduced and the average particle size became smaller (Schiettecatte et al., 2008; Zhu et al., 2016). However, when slope was greater than 15deg, the runoff eroding power was increased, and soil corrosion resistance and anti-scourability were reduced (Berger et al., 2010; Zhu et al., 2016). Meanwhile, the effect of vegetation on interception and sorting of eroded sediment particles was gradually decreased, thus Dx (10), Dx (50), and Dx (90) gradually stabilized under different vegetation covers.

\section{Conclusions}

The interacting effects of slope and vegetation cover on runoff and sediment yield characteristics of riparian slopes in the lower reaches of Yellow River, China, were investigated. The results indicated that runoff and sediment yield were greatly influenced by slope gradient at steep slope gradients (15deg and 20deg), and they mainly were affected by vegetation cover at medium slope gradients (5deg and 10deg). The enriched particle size of the eroded sediment showed a trend of first increasing and then decreasing with the increasing slope gradients. Regarding different slope gradients, Dx (10), Dx (50), and Dx (90) mainly were made up of silt, 
coarse powder grains and very fine sand, and very fine sand and fine sand, respectively.

Slope gradient had an extremely significant effect on the three sediment yield characteristics (runoff sediment concentration, accumulative sediment yield, and erosion sediment yield), and vegetation cover had an extremely significant effect on accumulative sediment yield and erosion sediment yield. Further, the effect of vegetation cover on the slope erosion sediment yield weakened gradually with increasing slope gradient (at medium slope gradients of $5 \mathrm{deg}$ and $10 \mathrm{deg}$ ), while the effect of slope gradient increased at steep slope gradients (15deg and 20deg).

\section{Acknowledgements}

This work was supported by the National Natural Sciences Foundation of China (41301197, 1971229, U1804119, 41771202), the Natural Science Foundation of Henan (202300410050), and the 2019 Young Backbone Teachers Foundation from Henan Province (2019GGJS030). We would also like to thank Prof. Simon Queenborough at the Yale University for editing the manuscript.

\section{References}

Alatorre, L.C., Begueria, S., Lanarenault, N., Navas, A., Garciaruiz, J.M., 2011. Soil erosion and sediment delivery in a mountain catchment under scenarios of land use change using a spatially distributed numerical model. Hydrol. Earth Syst. Sci. Discus. 8, 1321-1334.

Aoki, Sereno, A.M., 2006. Evaluation of infiltration as soil quality indicator by a micro rainfall simulator. Agriscientia. 23, 23-31.

Arnaez, J., Lasanta, T., Ruiz-Flano, P., Ortigosa, L., 2007. Factors affecting runoff and erosion under simulated rainfall in Mediterranean vineyards. Soil Till. Res. 93, 324-334.

Assouline, S., Ben-Hur, M., 2006. Effects of rainfall intensity and slope gradient on the dynamics of interrill erosion during soil surface sealing. Catena 66, 211-220.

Ai, N., Wei, T.X., Zhu, Q.K., Qiang, F.F., Ma, H., Qin, W., 2017. Impacts of land disturbance and restoration on runoff production and sediment yield in the Chinese Loess Plateau. J. Arid Land 9, 76-86.

Berger, C., Schulze, M., Riekezapp, D., Schlunegger, F., 2010. Rill development and soil erosion: a laboratory study of slope and rainfall intensity. Earth Surf. Proc. Land. 35, 1456-1467.

Bergkamp, G., 1998. A hierarchical view of the interactions of runoff and infiltration with vegetation and microtopography in semiarid shrublands. Catena 33, 201-220.

Breshears, D.D., Wilcox, B.P., Allen, C.D., 1998. Viewpoint: sustainability of Pinon-Juniper ecosystems: a unifying perspective of soil erosion thresholds. J. Range Manag. 51, 231-240.

Cadol, D., Wine, M.L., 2017. Geomorphology as a first order control on the connectivity of riparian ecohydrology. Geomorphology 277, 154-170.

Canton, Y., Sole-Benet, A., Vente, J.D., Boix-Fayos, C., Calvo-Cases, A., Asensio, C., Puigdefabregas, J., 2012. A review of runoff generation and soil erosion across scales in semiarid south-eastern Spain. J. Arid Environ. 75, 1254-1261.

Chen, L.D., Yang, B.J., Ran, H., 2012. Spatial scale effects of water erosion dynamics: complexities, variabilities, and uncertainties. Chinese Geogr. Sci. 22, 127-143.

Chen, L., Huang, Z., Gong, J., Fu, B.J., Huang, Y.L., 2007. The effect of land cover/vegetation on soil water dynamic in the hilly area of the Loess Plateau, China. Catena 70, 200-208.

Cheng, Q.J., Cai, Q.G., Liao, Y.S., 2007. Effects of soil surface characteristics and gradient on runoff and sediment yield. J. Soil Water Conserv. 21, 9-11. 
Cheng, Q.J., Ma, W.J., Cai, Q.G., 2008. The relative importance of soil crust and slope angle in runoff and soil loss: A case study in the hilly areas of the Loess Plateau, North China. GeoJournal 71, 117-125.

Cerda, A., 2001. Effects of rock fragment cover on soil infiltration, interrill runoff and erosion. Eur. J. Soil Sci. 52, 59-68.

Chen, L., Sela, S., Svoray, T., Assouline, S., 2013. The role of soil-surface sealing, microtopography, and vegetation patches in rainfall-runoff processes in semiarid areas. Water Resour. Res. 49, 5585-5599.

Donjadee, S., Chinnarasri, C., 2012. Effects of rainfall intensity and slope gradient on the application of vetiver grass mulch in soil and water conservation. Int. J. Sediment Res. 27, 168-177.

Duan, L.X., Huang, M.B., Zhang, L.D., 2016. Differences in hydrological responses for different vegetation types on a steep slope on the Loess Plateau, China. J. Hydrol. 537, 356-366.

Fox, D.M., Bryan, R.B., 2000. The relationship of soil loss by interrill erosion to slope gradient. Catena 38, 211-222.

Fox, D.M., Bryan, R.B., Price, A.G., 1997. The influence of slope angle on final infiltration rate for interrill conditions. Geoderma 80, 181-194.

Geng, S.M., Yang, D.H., Luo, X.X., Zheng, X.D., 2012. New evolution tendencies of flood disasters under changing environment in middle and lower reaches of the Yellow River. B. Soil Water Conserv. 32, 188-191

Gurnell, A., 2014. Plants as river system engineers. Earth Surf. Proc. Land. 39, 4-25.

Jiang, F.S., Huang, Y.H., Lin, J.S., Zhao, G., Ge, H.L., Lin, J.L., 2014. Effects of slope gradient and rainfall intensity on particle size composition of erosion sediment from colluvial deposits of benggang. Acta Pedol. Sin. 51, 974-982.

Jin, C.X., 1996. The role of slope gradient on slope erosion. Geogr. Res. 15, 57-63.

Joshi, V.U., Tambe, D.T., 2010. Estimation of infiltration rate, run-off and sediment yield under simulated rainfall experiments in upper Pravara Basin, India: Effect of slope angle and grass-cover. J. Earth Sys. Sci. $119,763$.

Liu, J.G., Zhang, X.C., Li, L., Huang, X.H., Xu, C., 2015a. Research of effect of vegetation coverage on soil and water loss in purple soil slope land. Res Soil Water Conserv. 22, 16-20.

Liu, D., She, D., Yu, S., Shao, G., Chen, D., 2015b. Rainfall intensity and slope gradient effects on sediment losses and splash from a saline-sodic soil under coastal reclamation. Catena 128, 54-62.

Liu, Q., Zhu, B., Tang, J.L., Huang, W.J., Zhang, X.F., 2017. Hydrological processes and sediment yields from hillslope croplands of Regosol under different slope gradients. Soil Sci. Soc. Am. J. 81, 1517-1525.

Lavee, H., Poesen, J.W.A., 1991. Overland flow generation and continuity on stonecovered soil surfaces. Hydrol. Process. 5, 345-360.

Li, P., Li, Z.B., Zheng, L.Y., 2006. Hydrodynamics process of soil erosion and sediment yield by runoff on loess slope. Adv. Water Sci. 17, 444-449.

Li, G.L., Zheng, T.H., Yu, F.U., Li, B.Q., Zhang, T., 2017. Soil detachment and transport under the combined action of rainfall and runoff energy on shallow overland flow. J. Mt. Sci. 14, 1373-1383.

Mendez-Toribio, M., Zermeno-Hernandez, I., Ibarra-Manriquez, G., 2014. Effect of land use on the structure and diversity of riparian vegetation in the Duero river watershed in Michoacan, Mexico. Plant Ecol. 215, 285-296.

Ma, B., Wu, F.Q., Li, Z.B., Wang, J., 2013. Interaction of crop cover and slope gradient on runoff and sediment yield. J. Soil Water Conserv. 27, 33-38. 
Mander, U., Hayakawa, Y., Kuusemets, V., 2005. Purification processes, ecological functions, planning and design of riparian buffer zones in agricultural watersheds. Ecol. Eng. 24, 421-432.

Mohamadi, M.A., Kavian, A., 2015. Effects of rainfall patterns on runoff and soil erosion in field plots. Int. Soil Water Conserv. Res. 3, 273-281.

Mohammad, A.G., Adam, M.A., 2010. The impact of vegetative cover type on runoff and soil erosion under different land uses. Catena 81, 97-103.

Molina, A., Govers, G., Cisneros, F., Vanacker, V., 2010. Vegetation and topographic controls on sediment deposition and storage on gully beds in a degraded mountain area. Earth Surf. Proc. Land. 34, 755-767.

Munoz-Robles, C., Tighe, M., Reid, N., Frazier, P., Briggs, S.V., Wilson, B., 2013. A two-step up-scaling method for mapping runoff and sediment production from pasture and woody encroachment on semi-arid hillslopes. Ecohydrology 6, 83-93.

Nunes, A.N., Almeida, A.C.D., Coelho, C.O.A., 2011. Impacts of land use and cover type on runoff and soil erosion in a marginal area of Portugal. Appl. Geogr. 31, 687-699.

Romkens, M.J.M., Helming, K., Prasad, S.N., 2001. Soil erosion under different rainfall intensities, surface roughness, and soil water regimes. Catena 46, 103-123.

Sandercock, P.J., Hooke, J.M., 2011. Vegetation effects on sediment connectivity and processes in an ephemeral channel in SE Spain. J. Arid Environ. 75, 239-254.

Sanguesa, C., Arumi, J., Pizarro, R., Link, O., 2010. A rainfall simulator for the in situ study of superficial runoff and soil erosion. Chil. J. Agr. Res. 70, 178-182.

Schiettecatte, W., Gabriels, D., Cornelis, W.M., Hofman, G., 2008. Enrichment of organic carbon in sediment transport by interrill and rill erosion process. Soil Sci. Soc. Am. J. 72, 50-55.

Sharma, A., Tiwari, K.N., Bhadoria, P.B., 2011. Effect of land use land cover change on soil erosion potential in an agricultural watershed. Environ. Monit. Assess. 173, 789-801.

Sirjani, E., Mahmoodabadi, M., 2014. Effects of sheet flow rate and slope gradient on sediment load. Arab. J. Geosci. 7, 203-210.

Srivastava, N.K., Ram, L.C., Masto, R.E., 2010. Role of selected riparian herbs in reducing soil erosion and nutrient loss under simulated rainfall. Environ. Earth Sci. 61, 405-417.

Stella, J.C., Rodriguez-Gonzalez, P.M., Dufour, S., Bendix, J., 2013. Riparian vegetation research in Mediterranean-climate regions: common patterns, ecological processes, and considerations for management. Hydrobiologia 719, 291-315.

Sachs, E., Sarah, P., 2017. Combined effect of rain temperature and antecedent soil moisture on runoff and erosion on Loess. Catena 158, 213-218.

Sadeghi, S.H.R., Seghaleh, M.B., Rangavar, A.S., 2013. Plot sizes dependency of runoff and sediment yield estimates from small watershed. Catena 102, 55-61.

Tang, Q., Bao, Y., He, X., Zhou, H., Cao, Z., Gao, P., Zhong, R., Hu, Y., Zhang, X., 2014. Sedimentation and associated trace metal enrichment in the riparian zone of the Three Gorges Reservoir, China. Sci. Total Environ. 479-480, 258.

Vasquez-Mendez, R., Ventura-Ramos, E., Oleschko, K., Hernandez-Sandoval, L., Parrot, J.F., Nearing, M.A., 2010. Soil erosion and runoff in different vegetation patches from semiarid Central Mexico. Catena 80, 162-169.

Valmis, S., Dimoyiannis, D., Danalatos, N.G., 2005. Assessing interrill erosion rate from soil aggregate instability index, rainfall intensity and slope angle on cultivated soils in central Greece. Soil Till. Res. 80, 
139-147.

Verbist, K., Cornelis, W.M., Gabriels, D., Alaerts, K., Soto, G., 2009. Using an inverse modelling approach to evaluate the water retention in a simple water harvesting technique. Hydrol. Earth Syst. Sci. 13, 1979-1992.

Wang, Z.J., Jiao, J.Y., Rayburg, S., Wang, Q.L., Su, Y., 2016. Soil erosion resistance of "Grain for Green" vegetation types under extreme rainfall conditions on the Loess Plateau, China. Catena 141, 109-116.

Wang, L., Ma, B., Wu, F., 2017a. Effects of wheat stubble on runoff, infiltration, and erosion of farmland on the loess plateau, china, subjected to simulated rainfall. Solid Earth 8, 281-290.

Wang, L., Dalabay, N., Lu, P., Wu, F., 2017b. Effects of tillage practices and slope on runoff and erosion of soil from the Loess Plateau, China, subjected to simulated rainfall. Soil Till. Res. 166, 147-156.

Wu, L., Peng, M.L, Qiao, S.S., Ma, X.Y., 2018. Assessing impacts of rainfall intensity and slope on dissolved and adsorbed nitrogen loss under bare loessial soil by simulated rainfalls. Catena 170, 51-63.

Xin, Z.B., Yu, X.X., Li, Q.Y., Lu, X.X., 2011. Spatiotemporal variation in rainfall erosivity on the Chinese Loess Plateau during the period 1956-2008. Reg. Environ. Chang. 11, 149-159.

Zhang, Y., Ding, Y.Y., Wang, D.A., Tan, S., Yang, Y., Liu, B.Y., 2015a. Effects of slope gradient on yield and particle size distribution of sediment. J. Soil Water Conserv. 29, 25-29.

Zhang, L., Wang, J., Bai, Z., Lv, C., 2015b. Effects of vegetation on runoff and soil erosion on reclaimed land in an opencast coal-mine dump in a loess area. Catena 128, 44-53.

Zhang, X.Q., Hu, M.C., Guo, X.Y., Yang, H., Zhang, Z.K., Zhang, K.L., 2018. Effects of topographic factors on runoff and soil loss in Southwest China. Catena 160, 394-402.

Zhang, X.N., Feng, J., Gao, Y.B., Liu, N.N., 2010. Influences of slope on runoff and concentration and solute transport under different rainfall intensities. Bull. Soil Water Conserv. 30, 119-123.

Zhao, Q.H., Li, D.Q., Zhuo, M.N., Guo, T.L., Liao, Y.S., Xie, Z.Y., 2015a. Effects of rainfall intensity and slope gradient on erosion characteristics of the red soil slope. Stoch. Environ. Res. Risk Assess. 29, 1-13.

Zhao, Q.H., Lu, X.L., Tang, Q., Zhang, Y.F., Liu, P., 2016. Fractal dimension characteristic of soil particle size in the riparian buffer zone of the middle and lower reaches of the Yellow River. Sci. Soil Water Conserv. $14,37-46$.

Zhao, Q.H., Ma, L.J., Liu, Q., Ding, S.Y., Tang, Q., Lu, X.L., 2015b. Plant species diversity and its response to environmental factors in typical river riparian zone in the middle and lower reaches of Yellow River. Chinese. J. Ecol. 34, 1325-1331.

Zhu, B.B., Li, Z.B., Li, P., You, Z., 2010. Effect of grass coverage on sediment yield of rain on slope. Acta Pedol. Sin. 47, 401-407.

Zhu, G.L., Wen, B., Li, J., Huang, Y.H., Zou, W., Lin, J.S., 2016. Particle size compositionof erosion sediment from colluvial depositsof collapsing hill as effected by rainfall intensity and coverage. Acta Pedol. Sin. 53, 1371-1379.

Zingg, A.W., 1940. Degree and length of land slope as it affects soil loss in run-off. Agric Engng. 21, 59-64. 

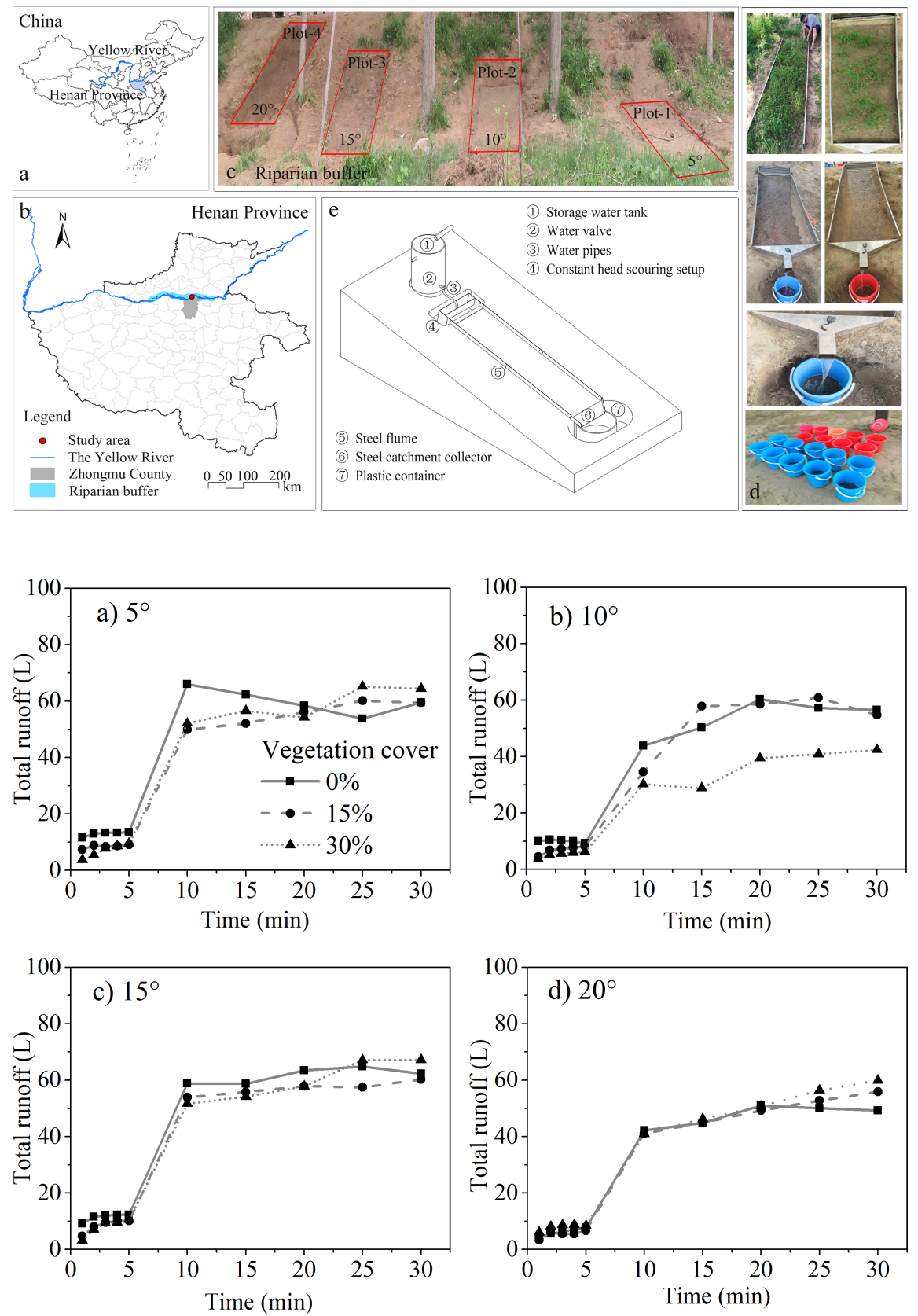

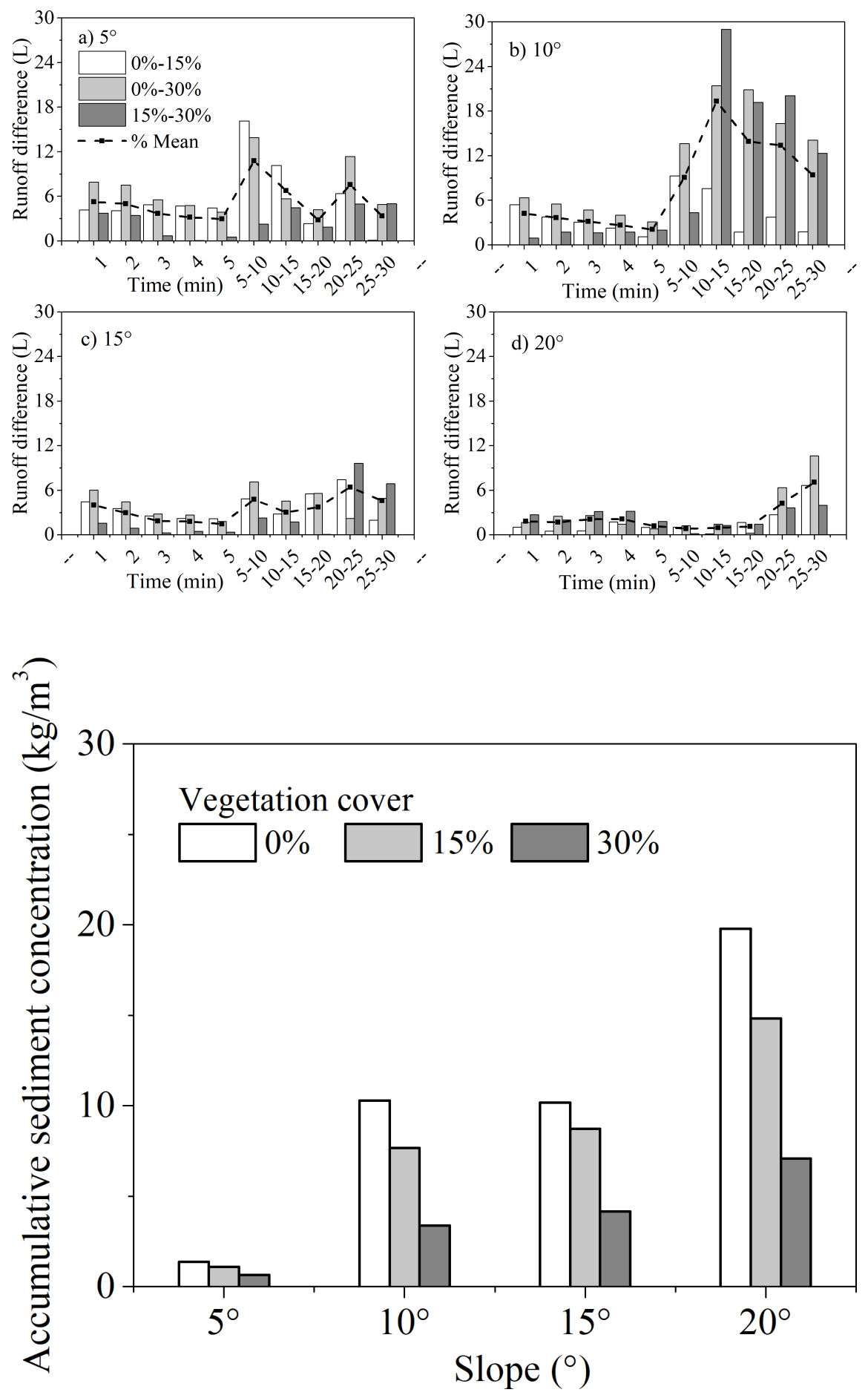

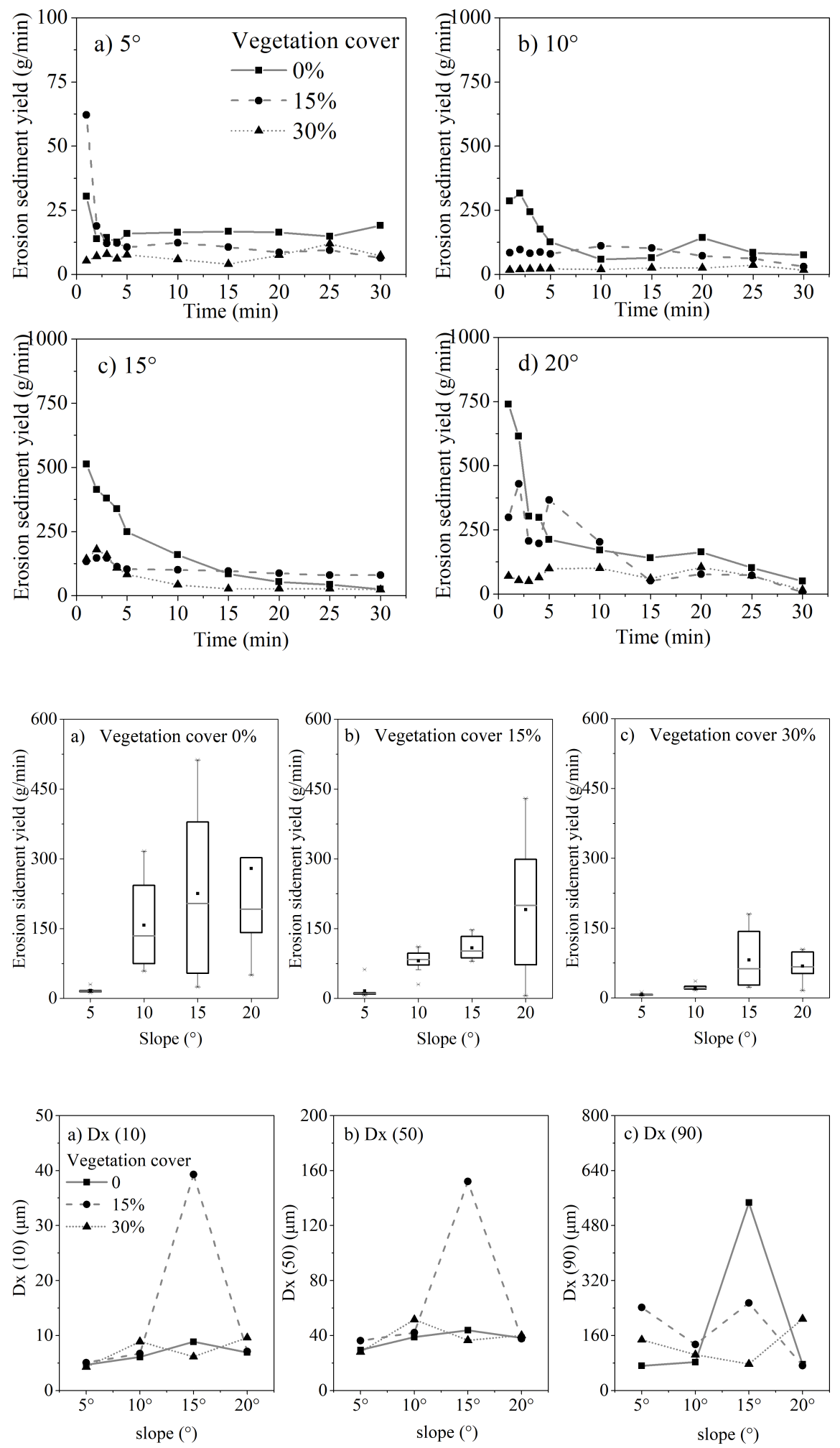
Accumulative sediment yield

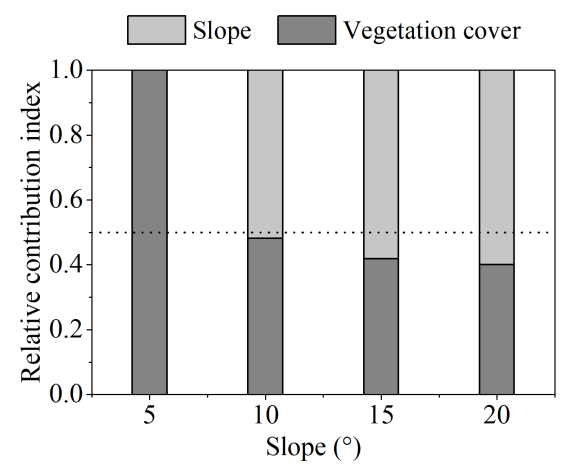

Runoff sediment concentration

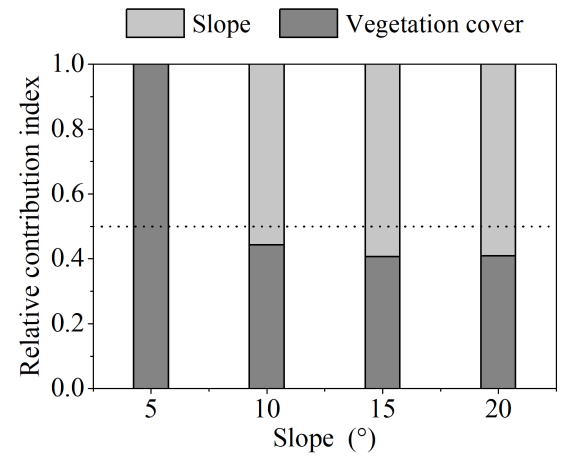

\section{Hosted file}

Tables.pdf available at https://authorea.com/users/414205/articles/522312-the-relativecontributions-of-slope-gradient-and-vegetation-cover-on-erosion-characteristics-ofriparian-slopes-along-the-lower-yellow-river-china 